\title{
Analysis of 128 Patients with Angiogram in Acute Head Trauma
}

\author{
M. P. CINESI, J. D. R. MILLER, M. GRACE AND T. N. AYERS
}

SUMMARY: $A$ computerized analysis of 128 patients admitted with acute head injury and who underwent angiography is shown. Patients were divided into groups according to: age, sex, type of accident, state of consciousness and presence of localizing signs on admission, types of cerebral lesions on angiography, and discharge condition.

There is a preponderance of young males in this series of patients, related mainly to MVA. A total of $71 \%$ of the

RÉSUMÉ: Une analyse par ordinateur de 128 patients admis avec un traumatisme crânien aigu et qui furent investigués par angiographie, est présentée. Les patients furent divisés en différents groupes suivant: l'âge, le sexe, le genre d'accident, l'état de conscience, la présence de signes localisés à l'admission, les types de lésions cérébrales sur l'angiographie, et la condition à la sortie.

Il y a une prépondérance de jeunes hommes dans cette série de patients. Un patients had abnormal angiograms, but the incidence of normal and abnormal results did not correlate significantly with any of the chosen parameters.

The same parameters were also analysed to assess their value as a prognostic index for the patient. The conclusion was drawn that the angiogram per se has no significant value as a prognostic tool, and that state of consciousness on admission is the best single index for prognosis.

total de $71 \%$ des patients avaient des angiogrammes anormaux, mais l'incidence de résultats normaux et anormaux ne correspondait significativement avec aucun des paramètres choisis.

Les mêmes paramètres furent aussi analysés comme index pronostic pour le patient. La conclusion tirée fut que l'angiogramme per se n'a pas de valeur significative comme instrument pronostic, et que l'état de conscience à l'admission est encore le meilleur index.
From the Sections of Neurosurgery and Radiology, University of Alberta, and the University of Alberta Hospital, Edmonton, Canada.

Reprint requests to Dr. M. P. Cinesi, University of Alberta Hospital, 112 St. and 83 Ave., Edmonton, Alberta, Canada T6G 2B7.

\section{INTRODUCTION}

The role of radiology in general, and cerebral angiography in particular, is well accepted in the evaluation of patients with acute head trauma. Since the pioneer studies of Moniz in 1927 , cerebral angiography has been the method of choice in the neuroradiological evaluation of patients with severe head trauma (Lofstrom, 1955; Hancock, 1961; Thomson, 1963). It is a relatively simple technique in experienced hands and is associated with a low incidence of morbidity and mortality.

This paper describes the experience of the Department of Radiology, University of Alberta Hospital, in the angiographic evaluation of $\mathbf{1 2 8}$ patients, admitted following acute head injury, during the years 1970-72.

\section{METHOD}

Patients were divided into groups, according to age, sex, type of accident, state of consciousness on admission, and clinical condition on discharge.

Three types of accidents were distinguished: motor vehicle accident (MVA), fall and assault. Localizing signs were either present or absent on initial physical examination. The state of consciousness of patients was described as follows:

a) stupor - varying degrees of mental confusion, without loss of consciousness

b) light coma - unconscious but responding to stimuli

c) deep coma - unconscious and not responding to stimuli

To analyse the angiographic findings, three main categories were established: extracerebral lesions 


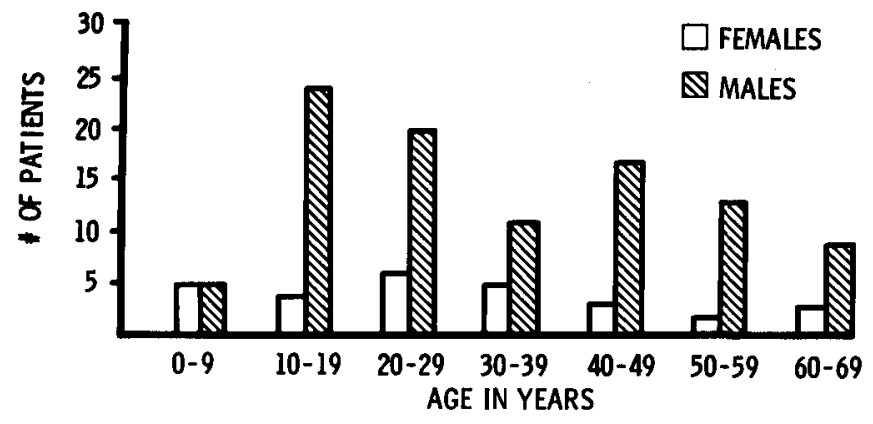

Figure 1-Distribution of 128 head injured patients as to age and sex.

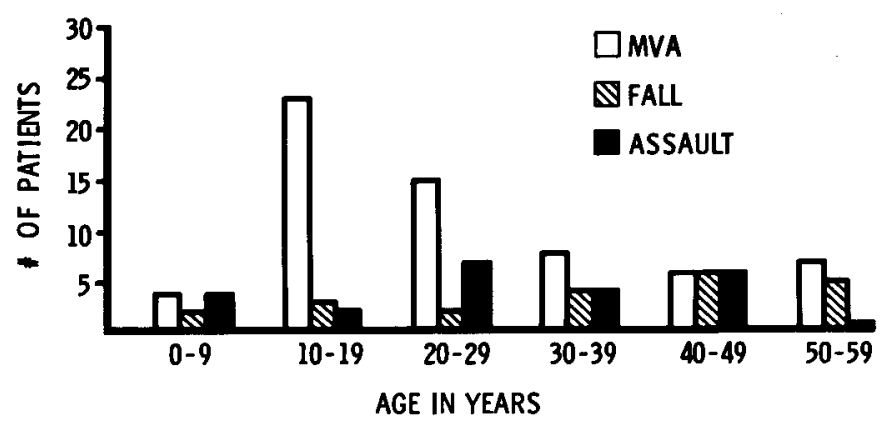

Figure 2-Age and type of accident of 128 head injured patients. (M.V.A. = motor vehicle accident). (subdural and extradural), intracerebral lesions (hematomas), and diffuse lesions associated with absent or diminished filling of the intracerebral circulation, making further angiographic localization impossible. The patient's condition on discharge was described as follows:

a) normal

b) minor sequelae - patients able to take care of themselves

c) major sequelae - patients requiring constant assistance

d) deceased

\section{ANALYSIS OF DATA}

A computerized statistical analysis (Nie, et al., 1970), was performed to assess the accuracy of angiography, and to compare the diagnostic value of the various parameters. Frequency distributions were compiled for all the variables, and tables developed to show the relationships between major variables; chi-square and other non-parametric tests were used to test the significance of these relationships.

RESULTS AND DISCUSSION

The distribution of patients ac- cording to age and sex (Fig. 1) shows that except for the 0-9 age group, there was a constant and marked male predominance, especially during the second decade, and after $\mathbf{4 0}$ years. Incidence of accidents for both sexes was higher in the 10-29 years group, in which $46 \%$ of all accidents occurred.

Motor vehicle accident was the leading cause of head trauma in almost all age groups, being responsible for $56 \%$ of all cases (Fig. 2). In the $10-19$ age group, $82 \%$ of injuries were due to this type of accident. Falls and assaults had equal incidence (22\%).

To evaluate the information resulting from angiography, the angiographic results were correlated with state of consciousness and presence or absence of abnormal physical signs, as these were recorded after neurological examination on admission. The correlation between state of consciousness and age group was statistically not significant (Fig. 4); however, there was a relatively higher incidence of stupor in the older groups. There were no significant relationships between groups and the presence or absence of physical signs (Fig. 3).

Correlation between normal or abnormal angiograms and age appears in Fig. 5. The incidence of abnormal angiograms was $71 \%$, but there was no significant relationship between incidence and age.

Evaluation of the angiograms in relation to the type of accident (Table 1) shows that the differences are not significant, except for the higher incidence of positive angiographic findings in patients who suffered falls.

The relationship between normal or abnormal angiograms and state of consciousness was also not significant (Table 2). A similar analysis of angiograms and localizing signs indicated no significant relationship (Table 3) $-74 \%$ of the patients with localizing signs had abnormal angiograms, as did $70 \%$ of patients without localizing signs.

To assess their possible prognostic value, the angiograms were correlated with the discharge condition of the patients; except in the deceased group, where the incidence of ab-

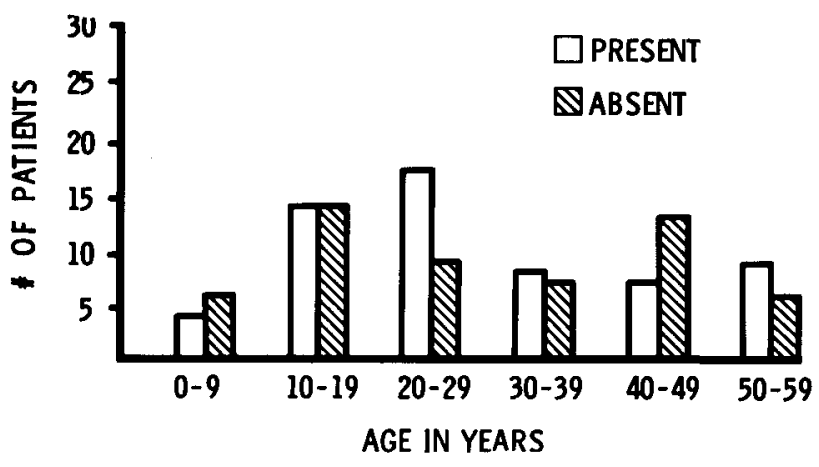

Figure 3-128 head injured patients divided into age groups and further categorized by presence or absence of physical signs (no relationship).

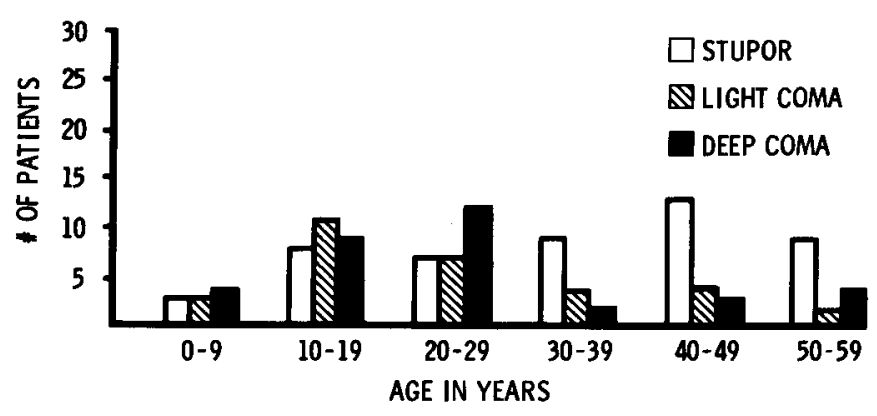

Figure 4-Correlation between state of consciousness and age groups (none). 
ANGIOGRAM \& TYPE OF ACCIDENT

\begin{tabular}{l|cc|}
\hline \multirow{2}{*}{$\begin{array}{l}\text { Type of } \\
\text { Accident }\end{array}$} & \multicolumn{2}{c}{ ANGIOGRAM } \\
Normal & Abnormal \\
\hline Mva & 20 & 45 \\
\cline { 2 - 3 } Fall & 4 & 27 \\
\cline { 2 - 3 } Assault & 7 & 16 \\
\hline Total & 31 & 88 \\
\hline
\end{tabular}

TABLE 1

ANGIOGRAM \& DISCHARGE CONDITION

\begin{tabular}{l|c|c|}
\hline & \multicolumn{2}{c}{ ANGIOGRAM } \\
$\begin{array}{l}\text { Discharge } \\
\text { Condition }\end{array}$ & $\begin{array}{c}\text { Normal } \\
\text { Angio }\end{array}$ & $\begin{array}{c}\text { Abnormal } \\
\text { Angio }\end{array}$ \\
\hline Normal & 11 & 19 \\
\cline { 2 - 3 } $\begin{array}{l}\text { Minor } \\
\text { Deficit }\end{array}$ & 7 & 23 \\
Major \\
Deficit
\end{tabular}

TABLE 4

\begin{tabular}{|c|c|c|}
\hline \multicolumn{3}{|c|}{$\begin{array}{l}\text { ANGIOGRAM \& STATE } \\
\text { OF CONSCIOUSNESS }\end{array}$} \\
\hline State of & ANG & JRAM \\
\hline Stupor & 15 & 39 \\
\hline $\begin{array}{l}\text { Light } \\
\text { Coma }\end{array}$ & 12 & 22 \\
\hline $\begin{array}{l}\text { Deep } \\
\text { Coma }\end{array}$ & 7 & 27 \\
\hline Total & 34 & 88 \\
\hline
\end{tabular}

TABLE 2

\begin{tabular}{l|c|c|}
\multicolumn{3}{c}{ ANGIOGRAM \& } \\
\multicolumn{2}{c}{ LOCALIZING SIGNS } \\
\hline $\begin{array}{l}\text { Localizing } \\
\text { Signs }\end{array}$ & $\begin{array}{c}\text { ANGIOGR A M } \\
\text { Normal }\end{array}$ & Abnormal \\
\hline Present & 16 & 46 \\
Absent & 18 & 42 \\
\hline Total & 34 & 88 \\
\hline
\end{tabular}

TABLE 3

STATE OF CONSCIOUSNESS \& DISCHARGE CONDITION

\begin{tabular}{|c|c|c|c|}
\hline \multirow[b]{2}{*}{$\begin{array}{l}\text { Discharge } \\
\text { Condition }\end{array}$} & \multicolumn{3}{|c|}{$\begin{array}{c}\text { STATE OF } \\
\text { CONSCIOUSNESS }\end{array}$} \\
\hline & Stupor & $\begin{array}{l}\text { Light } \\
\text { Coma }\end{array}$ & $\begin{array}{l}\text { Deep } \\
\text { Coma }\end{array}$ \\
\hline Normal & 22 & 7 & 1 \\
\hline $\begin{array}{l}\text { Minor } \\
\text { Deficit }\end{array}$ & 17 & 11 & 4 \\
\hline $\begin{array}{l}\text { Major } \\
\text { Deficit }\end{array}$ & 13 & 11 & 10 \\
\hline Deceased & 4 & 6 & 20 \\
\hline Total & 56 & 35 & 35 \\
\hline
\end{tabular}

TABLE 5 

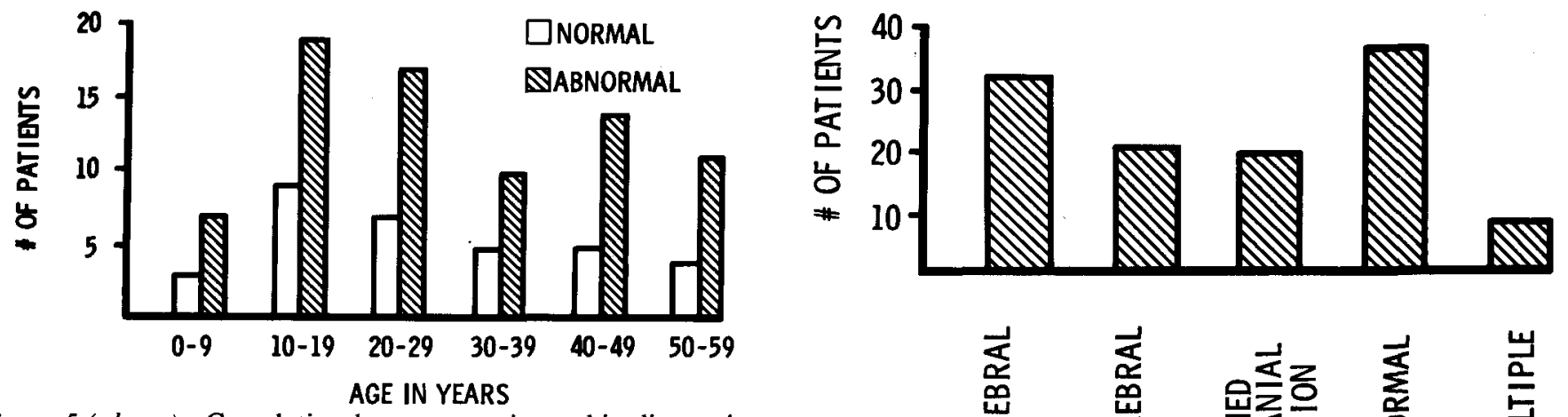

Figure 5 (above)-Correlation between angiographic diagnosis and age groups (none).

Figure 6(right)-Incidence of different types of cerebral lesions by angiographic diagnosis.

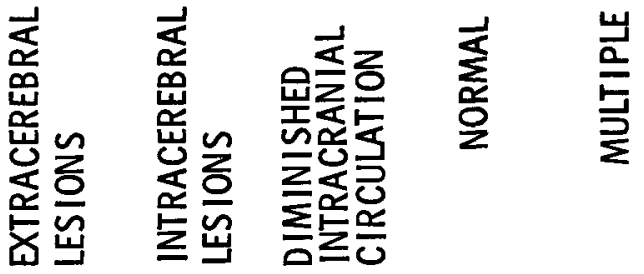

normal angiogram was $86 \%$, no significant differences were present between the normal, minor and major deficit groups (Table 4). This indicates that the angiogram per se is a poor prognostic tool.

However, analysis of condition on discharge in relation to the state of consciousness at admission (Table 5) was statistically significant ( $P$ 0.05 ), indicating that state of consciousness was the most valuable indicator in evaluating a patient's progress. Only $3 \%$ of patients admitted in deep coma were in normal neurological condition on discharge, while $66 \%$ died. Exactly the opposite was the case in the stupor group, with $73 \%$ of the patients being discharged in normal condition. The correlation between discharge condition and presence of localizing signs on admission shows no statistical significance (Table 6).

Figure 6 gives the incidence of the different types of cerebral lesions in this series; the extracerebral form predominates. Analysis of these lesions in relation to type of accident (Table 7), indicates that there is a higher incidence of intracerebral lesions in the MVA group; $66 \%$ of all intracerebral lesions occurred in this group. Extracerebral injuries occurred significantly more often in falls than did other types of lesions.

STATE OF CONSCIOUSNESS \& ANGIO DIAGNOSIS

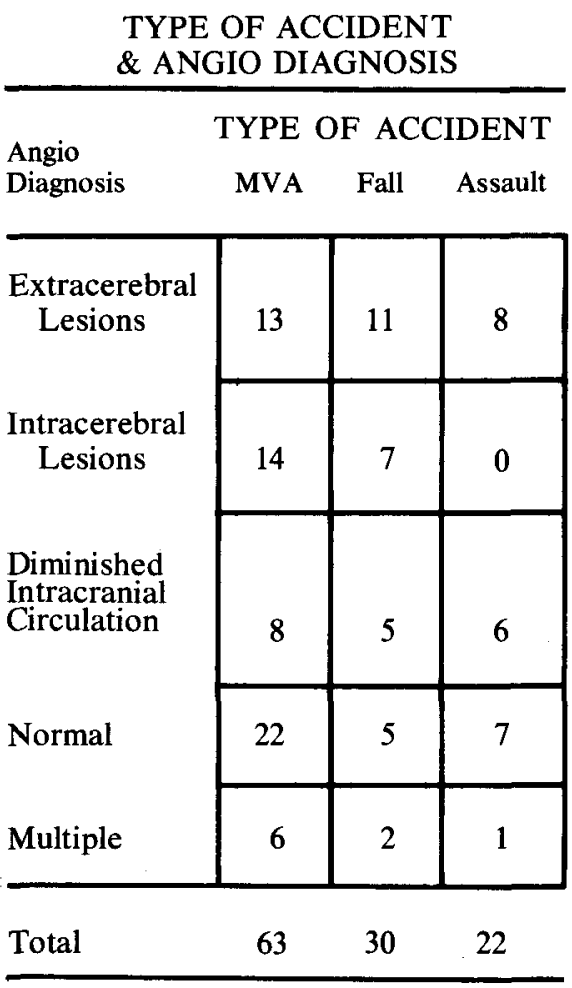

TABLE 7

\begin{tabular}{l|c|c|}
\hline & \multicolumn{2}{c}{ LOCALIZING SIGNS } \\
$\begin{array}{l}\text { Discharge } \\
\text { Condition }\end{array}$ & Present & Absent \\
\hline Normal & 15 & 15 \\
\cline { 2 - 3 } $\begin{array}{l}\text { Minor } \\
\text { Deficit }\end{array}$ & 15 & 17 \\
Major \\
Deficit
\end{tabular}

TABLE 6

LOCALIZING SIGNS \& DISCHARGE CONDITION 
LOCALIZING SIGNS

\& ANGIO DIAGNOSIS

LOCALIZING SIGNS

Angio

Diagnosis

Present Absent

\begin{tabular}{l|c|c|}
\hline $\begin{array}{l}\text { Intracerebral } \\
\text { Lesions }\end{array}$ & 19 & 13 \\
\cline { 2 - 3 } $\begin{array}{c}\text { Extracerebral } \\
\text { Lesions }\end{array}$ & 7 & 13 \\
\cline { 2 - 3 } $\begin{array}{l}\text { Diminished } \\
\text { Circulation } \\
\text { Normal }\end{array}$ & 14 & 6 \\
\cline { 2 - 3 } Multiple & 17 & 20 \\
\hline
\end{tabular}

Total

61

57

\section{ANGIO DIAGNOSIS \& DISCHARGE CONDITION}

\begin{tabular}{l|c|c|c|c|}
\hline \multirow{2}{*}{$\begin{array}{l}\text { Agnio } \\
\text { Diagnosis }\end{array}$} & \multicolumn{4}{c}{$\begin{array}{c}\text { DISCHARGE CONDITION } \\
\text { Minor } \\
\text { Deficit } \\
\text { Major } \\
\text { Deficit }\end{array}$} \\
\hline $\begin{array}{l}\text { Extracerebral } \\
\text { Lesions }\end{array}$ & 12 & 11 & 2 & 7 \\
\cline { 2 - 5 } $\begin{array}{l}\text { Intracerebral } \\
\text { Lesions }\end{array}$ & 2 & 4 & 8 & 7 \\
$\begin{array}{l}\text { Diminished } \\
\text { Intracranial } \\
\text { Circulation }\end{array}$ & 2 & 5 & 5 & 8 \\
Normal & 13 & 8 & 12 & 4 \\
\cline { 2 - 5 } Multiple & 0 & 1 & 4 & 4 \\
\hline Total & 29 & 29 & 31 & 30 \\
\hline
\end{tabular}

TABLE 10
The same breakdown of these lesions in relation to the state of consciousness (Table 8) is not significant, but nevertheless it is interesting to note that patients admitted in stupor and light coma had a higher incidence of extracerebral lesions, as opposed to the higher incidence of diminished intracranial circulation in patients admitted in deep coma, indicating the generalized cerebral damage in these patients. In Table 9 the same correlation is made with localizing signs, and the results are again not significant.

In the analysis of discharge condition relative to the different cerebral lesions (Table 10), $71 \%$ of the patients with extracerebral lesions were discharged in normal condition or with minor deficit, whereas in the intracerebral and diminished intracranial circulation groups $71 \%$ and $67 \%$ respectively were deceased or discharged with major deficits.
ACKNOWLEDGEMENT

We would like to express our thanks to Mrs. Faye Ramcharan for the excellent work done in the statistical analysis of the data.

\section{REFERENCES}

BISHARA, S. N.: Intracerebral Hemorrhage in Closed Head Injury. Brit. J. Surg. 58: 437-441, June 1971.

COLUMELLA, F., DELZANNO, G. B. and GAIST, G.: Angiography in Traumatic Cerebral Lacerations with Special Regard to Some Less Common Aspects. Acta Radiol. (Diagn.) 1: 239-247, March 1963.

DAVIS, D., BOHLMAN, H. and WALKER, A. E.: The Pathological Findings in Fatal Craniospinal Injuries. J. Neurosurg. 34: 603-613, May, 1971.

HANCOCK, D. O.: Angiography in Acute Head Injuries. Lancet. 745-747, September 1961.

LEIGHTON, R. S.: Neuroradiology in the Management of Acute Cranial Trauma. Roentgen. Europ. 6/7 (1963), 201.

LINDENBERG, R. and FREYTAG, E.: The Mechanism of Cerebral Contusions: A Pathologic-Anatomic Study. Arch. Path. 69: 440-469, 1960.
LOFSTROM, J. E., WEBSTER, J. E. and GURDJIAN, E. S.: Angiography in the Evaluation of Intracranial Trauma. Radiology 65: 847-855, December 1955.

MALONEY, A. F. J. and WHATMORE, W. $\mathrm{J} .:$ Clinical and Pathological Observation in Fatal Head Injuries. Brit. J. Surg. 56: 23-31, January, 1969.

NIE, N., BENT, D. H. and HULL, C. H.: Crosstabs and Code Book Reference SPSS Manual. McGrad Hill Codebook - pages 102-108, Crosstabs - pages 115-128.

RUDIKOFF, J. C., FERRIS, E. J. and SHAPIRO, J. H.: Intracerebral Vascular Rupture. Radiology 90: 288-291, February, 1968.

RUGGIERO, G., LEIGHTON, R. S. and DETTORI, P.: Acute Cranial Trauma: A Preliminary Report. Acta Radiol. (Diag.) 2: 487-496, November 1964.

SNEDECOR, G. W. and COCHRAN, W. G.: Statistical Methods, Iowa State University Press, 1967.

THOMSON, J. L. G.: Arteriography in Head Injuries. Clinical Radiol. 14: 339-348, 1963.

WEBSTER, J. E., DAWSON, R. E. and GURDJIAN, E. S.: The Diagnosis of Traumatic Intracranial Hemorrhage by Angiography. J. Neurosurg. 8: 368-376, July, 1951. 